\title{
Digital cartography for geoheritage: turning an analogue geotourist map into digital
}

\author{
Márton Pál, Gáspár Albert
}

ELTE Eötvös Loránd University, Department of Cartography and Geoinformatics, marchello@map.elte.hu, albert@ludens.elte.hu

\begin{abstract}
:
Geoheritage is the collective noun for the spectacular phenomena of geological and geomorphological landmarks that have to be preserved but also exploited by tourism in sustainable ways. The demonstration and preservation of these landmarks - the geosites - are often done in a geopark, an open area where they can be visited, and interesting facts can be learned of them through information boards. To provide visitors with an overall information of the geopark we need to create a geotourist map. This genre combines the characteristics of traditional tourist maps and geoscientific maps. Its purpose is to help tourists to navigate on the field and provide them with simplified geological content. Our mapping area is the eastern part of the Bakony-Balaton UNESCO Global Geopark in Hungary. An increasing number of tourist use their electronic devices to navigate on the field. Because of the growing need for smart maps we have decided to create two digital editions of our paper map. An OpenLayers-based version is ideal for planning: webpage visitors can easily find hiking trails and roads to the geosites. We have also decided to create the first geopark-thematized Android app in Hungary. It contains major information about geopark events, concepts of geoheritage, visitable geosites and tour guides. The most important feature is the geotourist map that is similar to the web version. With the help of geotourist maps, we are able to provide relevant geospatial information to hikers and visitors in an aesthetic way. These maps also help to raise awareness among people for geological and geomorphological heritage.
\end{abstract}

Keywords: geoheritage, geopark, geotourist map, Android, webcartography

\section{The role of geotourism}

Geoscientific research is mainly based on field work. The data is turned into synthesis and the results are communicated to the scientific community. However, due to the free data flow, research results are easily accessible for everyday non-scientific people nowadays. This generates interest on geoscience, unique natural phenomena and elements of our environment. According to the general definition, geotourism is a branch of tourism focusing on the touristic values of geological, geomorphological objects and landscapes (Newsome \& Dowling, 2010).

The geological and geomorphological values of our planet are represented by geosites. These are the most spectacular non-living phenomena of nature. Caves, cliffs, landscapes, rock outcrops, or even abandoned quarries turned into visitor's centres can be geosites. Choosing the most interesting features of a certain area is a complicated process. We have to take into consideration infrastructural and other aspects of tourism among scientific values (Hungarian Geological Society, 2017).

The main purposes of geotourism are the popularization of geosites as tourist destinations, preservation of geodiversity, raising awareness for environment protection and geoeducation: the apprehension of geosciences. Although the main focus is on geoheritage, sensitivity is also raised by geotourism towards cultural and historic values (Dowling, 2011).

Geotourism can be easily discerned from other branches of tourism. Its elements can be considered as tourist attractions because of the presentation of interesting geological formations and non-living natural heritage. In addition, local communities also learn of the values of these sites and work on making them more attractive for visitors. The satisfaction of geotourists and the work of inhabitants form the economic role: the monetary benefit is significant due to infrastructure development and workplace establishment (Dowling, 2011).

\subsection{Institutional background}

Geotourism, geoheritage and geoconservation meet in geoparks. These institutions are open for everyone interested in geoscientific, cultural and historic treasures of a certain area. Visitor centres, museums, well-preserved key sections with information boards and other services help visitors in geointerpretation (Bakony-Balaton Geopark, 2012).

Although some countries have started working on geoconservation and geoheritage earlier, the international institutional network was only established in the beginning of the $21^{\text {st }}$ century. The European Geoparks Network (EGN) was founded in 2000 by four geoparks. The need for a global organization was recognized within a few 
years, and the Global Geoparks Network (GGN) was established in 2004. All EGN and GGN members enjoy the membership and support of UNESCO that ensures highlevel protection and international prestige. There are 69 EGN and 140 GGN members (Figure 1) in 2019 from all over the world. Bakony-Balaton and Novohrad-Nógrád UNESCO Gobal Geoparks in Hungary are members of both international organizations (European Geoparks Network, 2019; Global Geoparks Network, 2019).

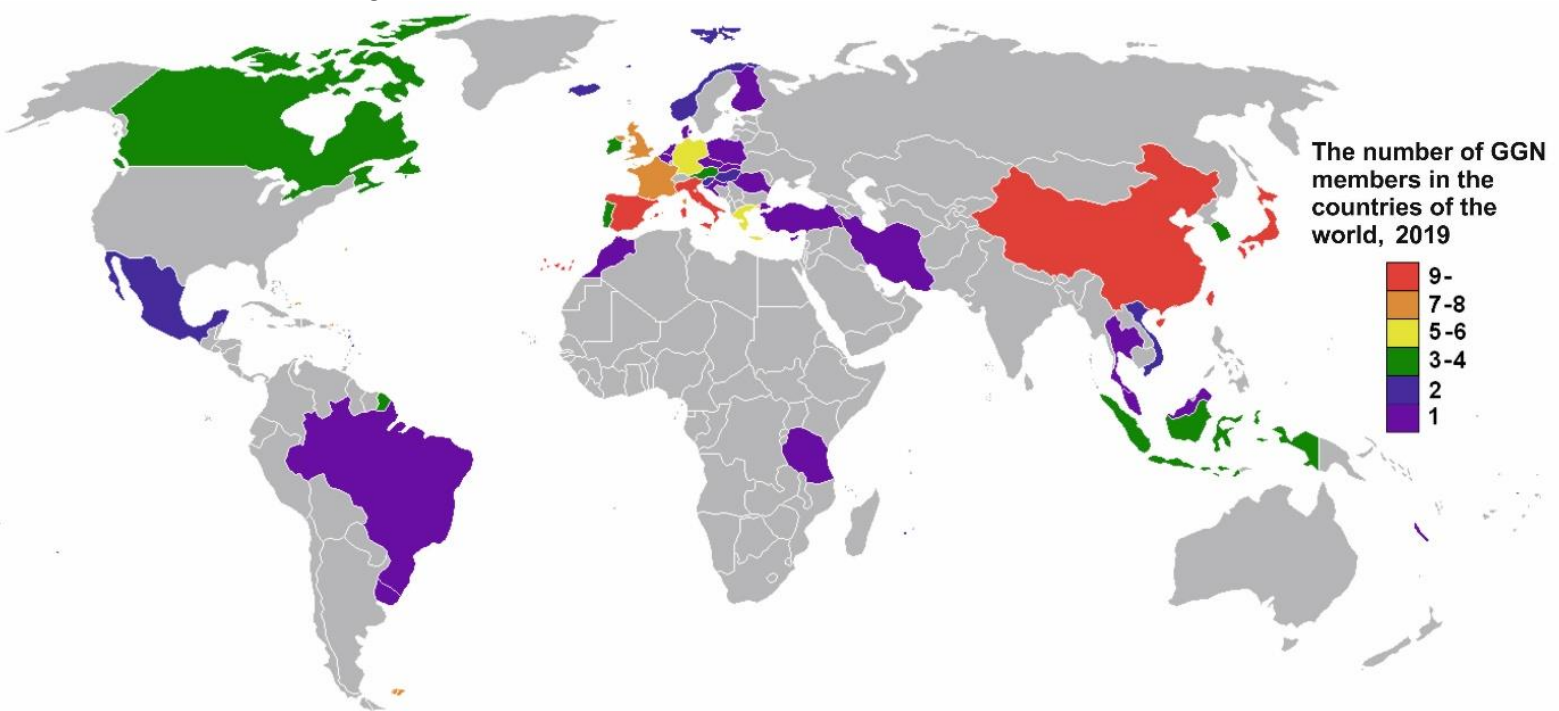

Figure 1. The distribution of GGN members around the world

\subsection{Bakony-Balaton UNESCO Global Geopark}

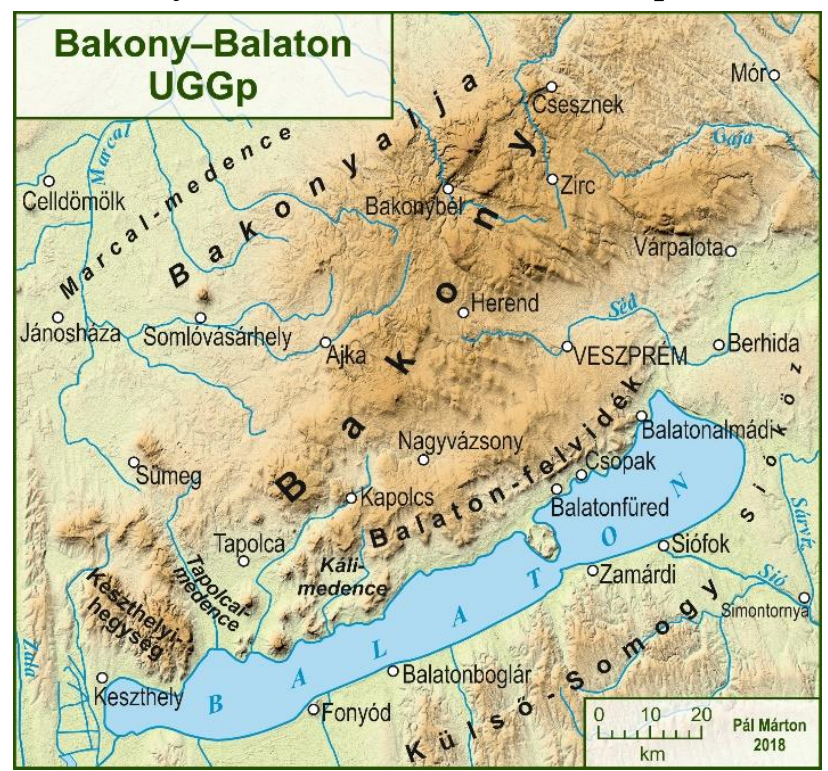

Figure 2. The extent of Bakony-Balaton UGGp.

Having an area over $3200 \mathrm{~km}^{2}$ the Geopark is a part of the Transdanubian Mountains (Figure 2). It includes the geological values of Bakony Mountains and Balaton Uplands. The covered area is notable for the beaches on the shore of Lake Balaton, thermal spas, wines and cultural heritage. It has mediterranean climate next to the lake, but it gets temperate and cooler on higher altitudes.

The exciting geological history and the diversity of formations were the basis for establishing a geopark. The main rocks are Permian red sandstone, Triassic limestone and dolomite on the eastern part. Tihany Peninsula and Tapolca Basin has volcanic features, but the surroundings of Tapolca has exciting karst features too. The dolomite of Keszthely Mountains is a base rock of some famous caves. Bakony Mountains is mainly built up by shallow sea limestone that forms fascinating cliffs. There are volcanic basalt residuals like Badacsony, Saint George's Mountain and Somló (Harangi, 2014).

This paper studies the proper and aesthetic visualization of geological features on analogue and digital platforms. The aim is to provide Geopark visitors with current information on geoscience and services.

\section{The genre of geotourist maps}

Tourist maps are well-known products of cartography all over the world. In Hungary hikers usually bring paper or digital tourist maps to their excursions. The scale and the content of these maps help users to navigate on the field: tourist routes, sights and other infrastructural facilities are highlighted.

Geological maps are mainly ordered by the sovereign state authorities. These are edited by mapping geologists. The first step of compiling such a map is fieldwork when an expert examines the area with the help of large-scale topographic maps. The observations are drawn on the field map sheets.

Topographic maps are the base for both tourist and geological maps. However, the content of their map keys is different, due to their function. Tourist maps contain elements related to field navigation while the elements of geological maps are connected to scientific results.

It is complicated for everyday people to get maps with geological content. If someone buys one, he/she faces the fact that these maps are hardly usable during trips: the geological layers cover topographic information. Until the last few decades the multiple use of geological and 
topographic-tourist maps was the solution for tourists who were interested in an area's geology.

Maps containing topographic information along with geological layers are called geotourist maps. (Albert, 2004).

\subsection{How does it look like?}

Interesting geological formations, outcrops and protected objects have been presented on maps in the USA, the UK and Canada before 1990. Some special geological maps have been produced for tourists since the end of the 1990s in Slovakia, Poland and the Czech Republic.

The Ore Mountains (Krušné Hory) is a famous tourist destination because of its significant and attractive natural sights. Most of the tourists in the area have not known about the richness of geology underneath. The first Central European attempts to make geotourist maps took place here in the mid-1990s. They used traditional topographic background with contour lines, planimetry and vegetation coverage. Geological formations and attractions were added to the top (Albert, 2004).

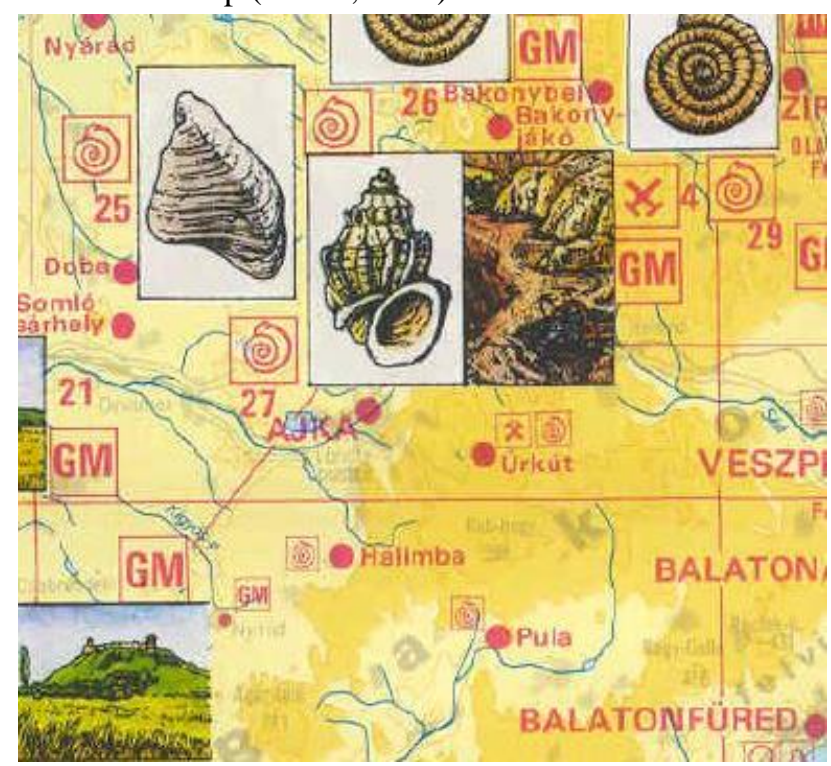

Figure 3. Geological curiosities of Hungary (Dank et al., 1989, excerpt)

The promoting of geology is a relatively new sector in Hungary, but there have been some attempts in the past decades to present exciting scientific results and sights. For example a 1:600 000-scale map was published in the late 1980s (Figure 3). It used pictograms and drawings to illustrate the most interesting sites. There is a constantly growing need for geological free time activities: more and more nature trails, visitor centres are established. These often mean the only opportunity for tourism in some areas. Lots of experts write and contribute in publications like tour guides, posters and maps to bring geoscience nearer to everyday people. The first large-scale geotourist map in Hungary was published in a guidebook in 2002 (Figure 4). As described by Albert (2004), the role of geological symbols is dominant on geological hiking maps (formations marked with unique colours, normal and reverse faults) but there are hiking trails, viewpoints, tourist attractions and traffic elements (road and railroad network, bicycle roads) also depicted. The topographic and geological content is in balance: the geothematic features countervail the detailed relief, planimetry and geographical names.

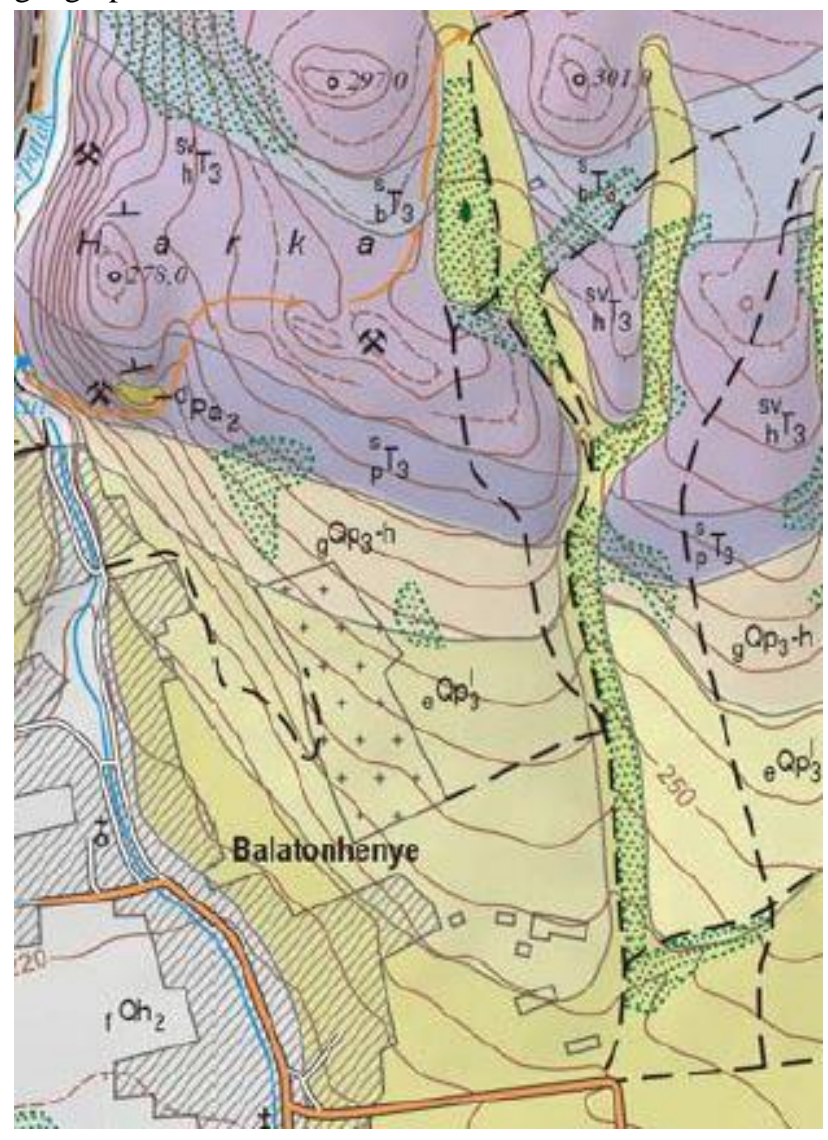

Figure 4. Geological hiking map of the surroundings of Balatonhenye (Albert, 2002, excerpt)

\subsection{Geoturist map types}

There are various uses on field of geotourist maps. Geopark staff and experts can use it as a working tool. Geodatabases detailed geosite descriptions can be used to predict further development strategies or natural hazards. (Bissig, 2008). Concerning geotourist there are two possible uses. The explaining function is essential during geotours: guides explain the geology of certain formations with the help of these publications. Geotourist maps help to understand scientific content in a didactic way. The exploring function is much more important: our maps help people to navigate on the field (Albert \& Pál, 2018). Thus, visitors rely on our work during their trip so we have to aim for the highest geographical precision. Rock types usually cannot be easily seen on the ground in Hungary because of the vegetation - except for the bare outcrops. So we have to provide precise information of the geological features as well.

Bissig (2008) have examined 51 geotourist maps from several countries and established 5 groups according to their geological content, form and graphical methods, but two of them were vaguely differentiated even by Bissig. 
From the aspect of cartography these maps are also categorized in rather four groups:

\subsubsection{Overview maps}

These maps are usually found in geopark brochures or other commercial booklets. The base map (which is sometimes a satellite image) includes main road and water network, simple relief. Geologically interesting information is marked with punctual symbols on a smallscale base map. This type is often not enough for field navigation as it contains only a few geological and tourist information.

\subsubsection{Tourist maps with poor geological content}

This type is characterized by larger scale and more detailed tourist information (picnic areas, car parks, accommodation, etc.) is depicted. The relief is depicted with contour lines, sometimes shading is also applied. Geosites, interesting outcrops and visitor centres are marked with punctual symbols but usually no other scientific content is presented.

2.2.3 Geoscientific maps for amateurs of Earth science - geological hiking maps

The members of this group can either be large$(>=1: 30000)$ or small-scale $(<1: 30000)$ maps. The difference from tourist maps is in the map key. It contains much more geological features like lithology and faults. Tourist facilities and geosites can be marked by punctual symbols or pictograms (depending on the scale). The relief is depicted with contour lines, shading is optional. This type is the most informative because of the high balance of tourist and scientific content.

\subsubsection{Interpretative, explanatory maps}

These maps are mainly used by geopark or national park staff members during geotours or any other guided tour. The schematic background, the simple and large pictograms and good colour choices help tourist to understand the main landscape and geological features of a certain area.

\subsection{Geological hiking map of the surroundings of} Csopak

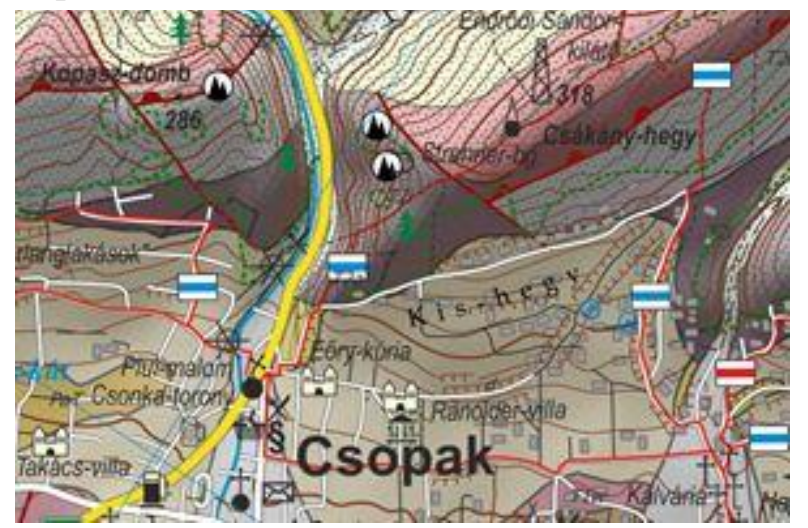

Figure 5. Geological hiking map of the surroundings of Csopak (Albert et al., 2018, excerpt)

Hungary's first large-scale geotourist map depicting geological formations and topographic-tourist elements in details has been published in 2018 (Figure 5). The 1:30 000 geological hiking map contains important facilities related to tourism and geotourism as well as geology.

This is also one of the first published map edited in opensource GIS environment (QGIS 2.18) in Hungary. For online publication QGIS work is an excellent material.

The relief is depicted with the help of contour lines, and we have also applied soft grey shading. The lithology is simplified (some formations are merged) along with vegetation and built-in areas. This step was essential to keep the map readable. All topographic and tourist elements are the same as on another tourist map.

One of the most important elements of geotourist map editing is geosite assessment, the search for the most important and exciting geological features of a certain area. Some GIS functions can be used on our vector data like filtering, spatial queries, buffer zones and clustering in order to select the appropriate places (Pál \& Albert, 2018). We have gathered thousands of POIs from different topographic and thematic maps. This amount of information cannot be presented on a map, so we had to filter these objects. We have applied the OpenStreetMap's settlement and industrial area layers and the Hungarian Geological Survey's (MBFSZ) mining cadastral to filter out points that fall into these areas. We have complemented this set with the list of protected key sections. The tools of GIS helped us in the evaluation process too. Spatial queries were used to determine the rarity of geological formations. Buffer zones were formed to count some map elements (e.g. national and cultural values around a geosite), and to measure the vicinity of visitors' centres, hostelry and restaurant services and other tourism infrastructure.

In Hungary tourist maps are often edited in a graphic design software. This means that basically they are no compatible with GIS, only paper and online PDF publication is available. The QGIS environment consisted of geodatabase files (SHPs and GeoJSONs) is a good decision to set up applications and online maps.

\section{Digital maps for geoheritage in Hungary}

Electronic devices are becoming a part of our life including hiking and visiting tourist attractions too. Fewer and fewer people use paper maps due to GPS devices and smartphone applications. The map reading ability of the population is decreasing. These factors put cartographers into a difficult situation.

The production of webcartographic have started to emerge after the foundation of GoogleMaps, OpenStreet Maps and other open map sources. There are some programming languages (JavaScript, Python) and feature-packed libraries inside HTML files (OpenLayers, Leaflet) that let any cartographer to edit a dynamic and aesthetic webbased map. With this step, all GIS-made maps could be inserted to any online directory. We have decided to build our map using OpenLayers. This library has immense forum support and additional scripts can be easily written using JavaScript language (Figure 6). 

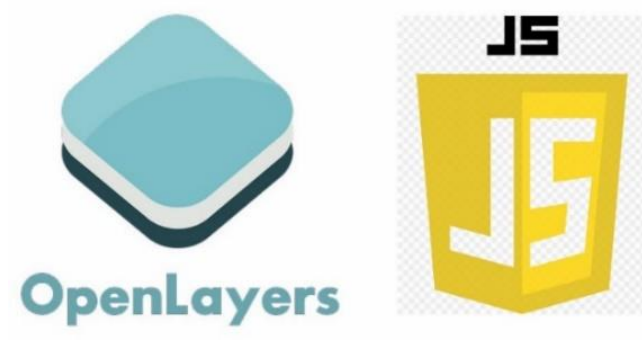

Figure 6. The logos of OpenLayers and JavaScript

Smartphone map apps are getting more and more popular not only amongst young people. As GoogleMaps and OpenStreetMaps base maps can be used nearly in every kind of application, people use them for car and personal navigation, for GPS tracking and to navigate on field with the help of hiking route layers. Android (with Java programming language) is one of the leader mobile operating systems (Figure 7). We have decided to use it because there are more Android phones and it is free to build apps and learn from lots of examples through online courses.

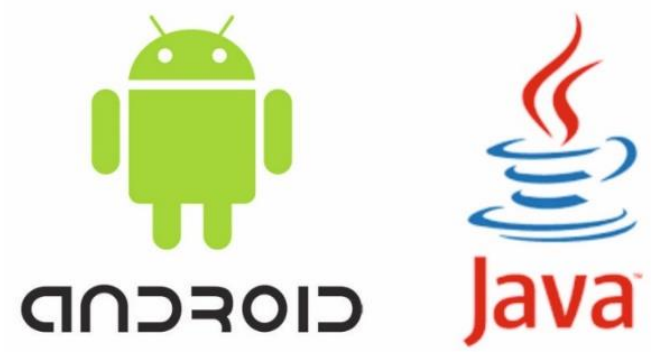

Figure 7. The logos of Android and Java

Some geoparks around the world has already edited their own mobile application, but only a few of them contains dynamic web-based cartographic woks. Our web map and smarthone app are the first Hungarian attempts to promote a geopark, geological features and even the whole geoheritage through online platforms.

\subsection{OpenLayers-based web map of Bakony-Balaton UNESCO Global Geopark}

After the consultation with the management of the Geopark we started to build up the content structure of such an OpenLayers map. We could not use the all the materials of the preliminary published analogue map, because the plan was to compile a map to the whole area of the Geopark. This meant much harder work, because all geological and geotourist content should have been digitized or prepared. The map is consisted of 4 basic layer groups:

1. Tiled grayscale raster background maps;

2. GeoJSON polygon layers for geological formations;

3. GeoJSON vector line layers;

4. GeoJSON point layers for geotourist features.

We have tried to apply simple design where users can easily find how to activate the features of the map. There are some hyperlinks on the right side of the page where visitors can access geopark-related pages. We have also edited a page that introduces our analogue paper map.
There is also a small JavaScript game: a picture of Hegyestü, a famous geosite of the geopark is available as a puzzle.

It is important, that the webpage is under construction. We are waiting for the suggestions of Geopark staff and looking forward for the opinion of the page visitors. We are going to develop the map accordingly to these reactions.

The webpage with the map is currently available here: http://mercator.elte.hu/ z3igaj/geoweb.

\subsubsection{Tiled grayscale raster background maps}

When editing a webpage for the dynamic map we need an HTML div element for the map itself. It is easy to insert any open source maps to this element (e.g. OpenStreetMap, Thunderforest maps and Mapbox - with registration and valid API key). With this step we have a custom basic topographic background.

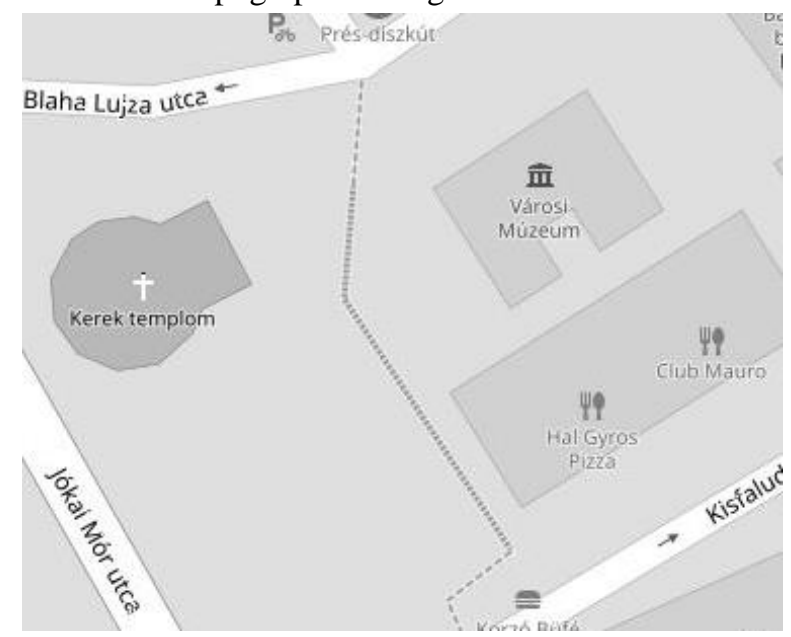

Figure 8. Excerpt of the grayscale OSM base map

The additional GeoJSON layers use lots of colours. Thus we decided to convert every inserted base map to grayscale. For this we used JavaScript function that examines the luminance and RGB value of each pixel and converts them into the appropriate grey value (Figure 8).

We can face several advantages of this visualization. The additional layers with some opacity are more visible due to the contrast and the full content of the base map is also visible.

\subsubsection{GeoJSON polygon layers for geological formations}

OpenLayers is capable to handle vector formats: we can easily add GeoJSON files to our script. We chose the 1:100 000 scale geological map of Hungary (Gyalog \& Síkhegyi, 2005) to be digitized for the Geopark area. The content of this scale is appropriate for geotourists. The original lithology colours were applied and a legend was also compiled.

We have applied 0.4 for opacity value for all polygons. If we magnify into the map, this value let us to "see through" the geological layer, and the base map's data content is clearly visible. It is important because of tourism aspects: roads, restaurants, important infrastructural buildings can 
also be seen in this way, so we do not need another layer for them.

By clicking on a polygon feature on the lithology layer, one can get its geological index attribute. We used online code sources such as the FeatureTooltip script and modified them ${ }^{1}$. The attributes are visible only when we click on a polygon (Figure 9).

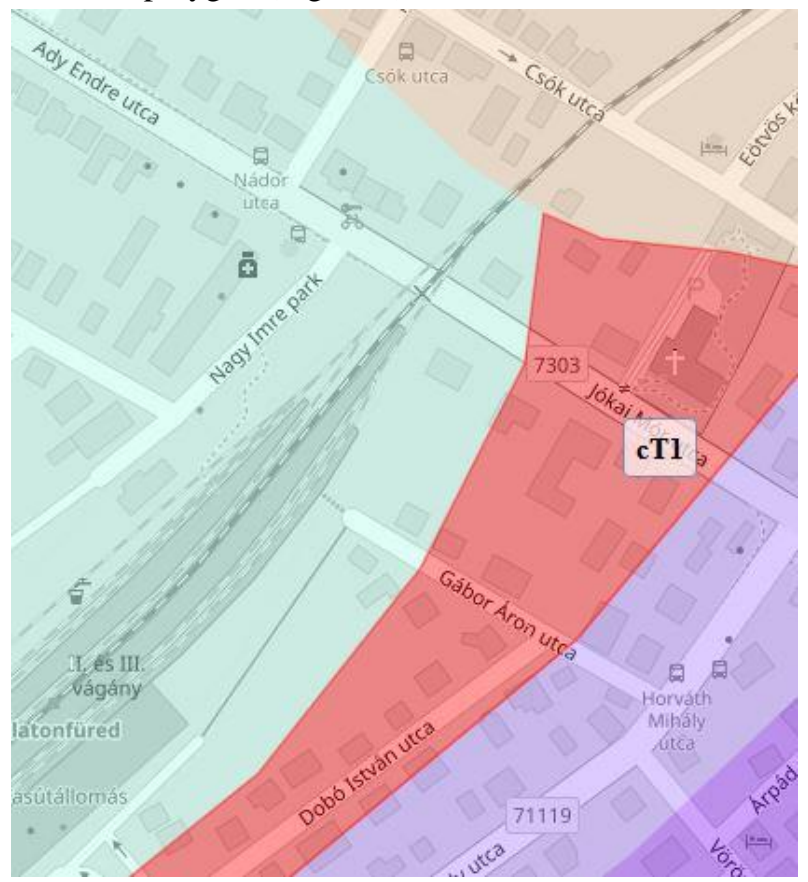

Figure 9. The lithology layer with an index popup.

\subsubsection{GeoJSON vector line layers}

OpenStreetMap data can be used for free for any open projects. The OSM database also includes hiking trails and bicycle paths. If we download these features from the server, they can also be exported as GeoJSON files and added to the web map.

If the scale is too small and all vector lines are visible, map content can be unreadably dense. In order to avoid this issue, we have applied scale-based visibility. It means that these layers can only be seen if we magnify the map to certain scale.

\subsubsection{GeoJSON point layers for geotourist features}

Gesoites, visitors' centres, museum, nature trails and other geologically significant and interesting places can be added to a map, using punctual symbols or pictograms. We have decided to use simple circles to visualize this content (Figure 10). This helps to keep the readability of the map in various scales. Opacity was also set to the fill of the circles in this case to see layers beneath the points.

These features are also clickable: we used again the modified version of the FeatureTooltip script. Links and a short description was also added to the small popup window in some cases.

\footnotetext{
${ }^{1}$ Mátyás Gede's original script shows a certain attribute of a layer when hovering. Instead, we have inserted the "click" event.
}

\subsection{Android smartphone application of Bakony- Balaton UNESCO Global Geopark}

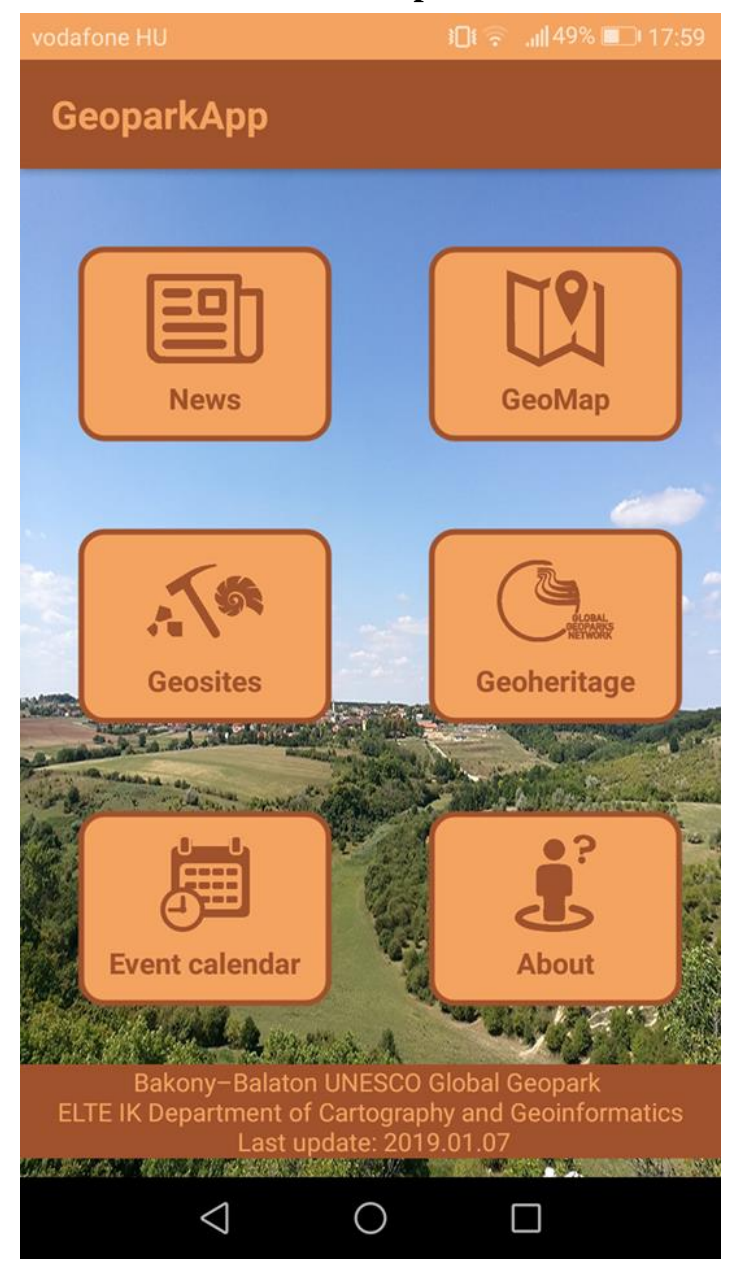

Figure 10. The main menu of the smartphone application

As some other geoparks already have mobile apps, we decided together with the Geopark staff that we start to develop our own application (Figure 11). The main functions were considered to be some information about the Geopark, its events, geoheritage, and the most important geosites and a map that can be used during hiking.

The application is considered to promote the website of the Geopark. Because of this most of the contents have links to its webpage. But we have created the geosite information window and a dynamic map window.

Android apps can be produced within the Android Studio PC application with the use of Java and XML languages. The XML is responsible for most of the design while Java does the events and handles interactions. Another available programming language is Kotlin. The main menu and the geosite information window were composed within Android Studio.

Android provides a window scheme called WebView. This enables our application to load and webpage content to our viewport. With the use of this no new in-built web map is 
needed for the app. The WebView is capable to handle the presented online webpage. In this way we get the same visual experience.

\section{Further plans}

These first versions of web and mobile applications will be developed in the future. We plan to add some built-in questionnaires that users can fill. We would like inquire about their opinion concerning the applications' design and functions. By the acknowledgement of these we will be able to develop to become user friendlier.

The questionnaires could serve a scientific purpose too. There is a project on geotourism and geoheritage in our research group. We can use these apps to gather opinions about geosites, geosite and geopark management, general scientific knowledge and interests. With these interviewing methods some other research can earn profit from these apps.

In addition, the publication of the analogue geological hiking map continues too. The next area is the neighbouring Tihany Peninsula and Pécsely Basin. We would like to edit these kind of maps continuously for the whole area of the Geopark. If it will be ready, we will be able to add our own geological polygon files to the web map.

\section{Cartography and geoheritage}

Cartography is an interdisciplinary science. Earth sciences, biology, history, politics, agriculture - almost every field of our life can earn from the coproduction with cartographers. This is also true for geoheritage and geotourism management. With the relatively new tools of GIS we are able to draw consequences from any kind of measured and sensed data. With the visual standards and rules of cartography we are able to produce aesthetic products and publications that help everyday people to reach for interpretable and relevant research results. These confirm that cartography and GIS are renewable fields of science.

The profit of using the tools of our specialization in geoheritage is clearly visible. We are able to determine which geosite deserves further development, what kind of natural hazards can occur in the area and the need of visiting tourists. Mapmaking is just a small subset of this large set of functions. The result of this work is a sustainable and environment friendly network that esteems the treasures of our planet.

\section{Acknowledgement}

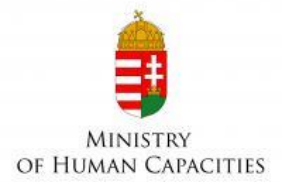

Márton Pál was supported by the ÚNKP18-2 New National Excellence Program of the Ministriy of Human Capacities.

\section{References}

Albert, G. (2004). Geoscientific results in "tangible" format: the geotourist map. - only in Hungarian: Földtudományok eredménye „kézzelfoghatóan”: a földtani túratérkép. Geodézia és kartográfia, 51(7), pp. 27-30.

Albert G. in Budai et al. (2002): Geological excursions I. - Balaton Uplands - only in Hungarian: Geológiai kirándulások I. - A Balaton felvidék, Balaton Uplands National Park Directorate, Veszprém 2002.

Albert, G., \& Pál M. (2018). Geotourist map: communication between geostaff and tourists. Abstracts Book, 8th International Conference on UNESCO Global Geoparks: Geoparks and sustainable development, p. 107.

Albert, G., Pál, M., \& Schwarcz, Gy. (2018). Geological hiking map of the surroundings of Csopak. 1:30 000, Schwarcz Térkép.

Bakony-Balaton Geopark. (2012). What is a geopark? only in Hungarian: Mi a geopark? Source: http://geopark.hu/home/mi-a-geopark [accessed: 2019.03.18.]

Bissig, G. (2008). Mapping geomorphosites: an analysis of geotourist maps. Geoturystyka 3 (14) 2008, pp. 3-12.

Dank V. et al. (1989). Geological curiosities of Hungary (1:600 000). Central Geological Office, Cartographical Establishment, Budapest.

Dowling, R. (2011). Geotourism's Global Growth. In Geoheritage, 3(1) (pp. 1-13.).

European Geoparks Network (2019): Meet our Geoparks. Source:

http://www.europeangeoparks.org/?page_id=168

[accessed: 2019. 03.18.]

Global Geoparks Network (2019). Member list. Source: http://www.globalgeopark.org/aboutGGN/list/index.htm [Accessed: 2019.03.18.]

Gyalog L., \& Síkhegyi F., eds, Geological map of Hungary. (scale: 1 : 100 000). Budapest, Hungary: Geological Institute of Hungary, 2005.

Harangi, S. (2014). Volcanic heritage of the CarpathianPannonian region in eastern-Central Europe. In Volcanic Tourist Destinations (pp. 103-123). Springer, Berlin, Heidelberg.

Hungarian Geological Society (2018). Geosite Day - only in Hungarian: Geotóp Nap. Source: http:/geotopnap.hu/ [accessed: 2019.03.18.]

Newsome, D., \& Dowling, R. (2010). Geotourism: The Tourism of Geology and Landscape.

Pál, M., Albert, G. (2018). Identifying outcrops for geological hiking maps. $7^{\text {th }}$ International Conference on Cartography and GIS - Proceeding vol. 1, pp. 103-108. Sofia, Bulgaria. 